$\underline{\text { Resumen Original / Resúmen Original }}$

\title{
DETERMINATION OF PHYTIC ACID IN URINE BY INDUCTIVELY COUPLED PLASMA MASS SPECTROMETRY
}

\author{
J.A. Muñoz Martínez, M. Valiente Malmagro*
}

Grup de Tècniques de Separació en Química (GTS), Química Analitica, Departament de Quimica, Universitat Autònoma de Barcelona

\section{Introduction}

Phytic acid (inositol hexakisphosphate) is a naturally occurring component in integral cereals and plant seeds ${ }^{1}$. A variety of benefits of phytic acid on human health are now recognized ${ }^{2-4}$, including an interesting beneficial action on some pathological processes such as calcium urolithiasis by preventing, at very low concentrations, the development of renal solid concretions. Consequently it has been proposed as a promising drug to treat calcium oxalate and phosphate stone formers ${ }^{5,6}$, since in humans between $1-10 \%$ of the total ingested phytic acid is excreted by the urine ${ }^{7}$. Accordingly, increasing the urinary excretion of phytic acid is recommended to diminish the risk of calcium oxalate and calcium phosphate kidney stone recurrence ${ }^{8}$.

The growing interest in the biomedical implications of phytic acid and the inherent problems with its detection are reflected in the diverse analytical techniques used for its determination ${ }^{9-14}$. However, the sensitivity of most of the current methodologies does not permit to ordinary laboratories an easy application to determine phytic acid in biological fluids (as urine) due to the low levels found in such a complex matrix. Furthermore, previous methods for phytic acid determination in urine ${ }^{13,14}$ are characterized by long, tedious sample 
treatment (purification, hydrolysis, derivatization, freeze-drying...) preceding the measurement of the analytical signal.

In this paper, a method for phytic acid determination in urine based on the purification of phytic acid by anion exchange and total phosphorus determination in the purified extract by ICP-MS (Inductively Coupled Plasma-Mass Spectrometry), as a high sensitive detection system. Thanks to its low detection limit, ICP-MS as detection system allow for an accurate determination of low amounts of phytic acid in urine through total phosphorous quantification after an effective anion-exchange separation process from other phosphorous compounds present in the sample matrix, with no need of pre-concentration step even when using low amounts of sample (1 mL of urine).

\section{Objective}

The aim of this work is to provide a simple and accurate analytical procedure to easily determine phytic acid in urine, in contrast with time-consuming current methods.

\section{Methods}

Reagents and apparatus

All chemical used were of analytical-reagent grade. Myoinositol hexaphosphoric acid hexasodium salt from corn was purchased from Sigma (Steinheim, Germany). AG 1x8 200-400 mesh, chloride form, anion exchange resin was from Bio-Rad Laboratories (Hercules, CA, USA).

$\mathrm{pH}$ was measured using a Crison $\mathrm{pH}$ meter micropH 2002 (Barcelona, Spain) with a combined glass electrode. ICP-MS model PQ-Excell (Thermo Elemental, UK) was used for phytic acid determination by total phosphorus measurement.

\section{Procedures}

In order to improve the mechanical characteristics of the anion-exchange separation of phytic acid from phosphate and other phosphorus compounds present in the urine matrix, urine samples are filtered through a $0.45 \mathrm{~m}$ upore filter prior to the purification process. Then, $1.0 \mathrm{~mL}$ of filtered urine is transferred quantitatively to a solid phase extraction cartridge, prepared with $1.5 \mathrm{~mL}$-syringe reservoir with 
$20 \mu \mathrm{m}$ frits containing $0.2 \mathrm{~g}$ of $\mathrm{AG} 1 \times 8$ resin, which was conditioned with $\mathrm{HCl} 50 \mathrm{mmol} \mathrm{L}^{-1}$ before use. Phosphate and some other matrix components of urine are eluted with $50 \mathrm{~mL}$ of $\mathrm{HCl} 50 \mathrm{mmol} \mathrm{L}^{-1}$. Finally the column is washed with $2 \mathrm{~mL}$ of $\mathrm{HCl} 2 \mathrm{~mol} \mathrm{~L}^{-1}$ to elute phytic acid. These purification processes are run by gravity (flow rate of $0.33 \mathrm{~mL} \mathrm{~min}^{-1}$ ).

The $2 \mathrm{~mL}$ of purified extract are diluted to $10 \mathrm{~mL}$ in a volumetric flask to avoid problems related with total acid content in the ICP-MS system. The determination of phytic acid is then carried out through ${ }^{31} \mathrm{P}$ analysis of the purified extracts of phytic acid from urine by ICP-MS using ${ }^{45} \mathrm{Sc}\left(10 \mu \mathrm{g} \mathrm{L}^{-1}\right)$ as an internal standard.

Urine samples were analysed immediately after collection in thermostatic containers. Otherwise urine samples should be acidified with $\mathrm{HCl}$ to $\mathrm{pH} 3-4$ to avoid precipitation and subsequent adsorption of phytic acid on the precipitates formed, which could lead to deficient recoveries of phytic acid from analysed samples.

\section{Results}

\section{Study of the separation/recovery processes}

The main problem of phytic acid determination in urine by ICP techniques lies in the presence of very low concentrations of phytic acid $\left(10^{-6} \mathrm{~mol} \mathrm{~L}^{-1}\right)$ in a matrix rich in phosphate $\left(10^{-2} \mathrm{~mol} \mathrm{~L}^{-1}\right)$.

Consequently, urinary phytic acid determination through phosphorus analysis by ICP-MS requires an extensive purification of phytic acid.

According to previous papers, the best results of purification and recovery of phytic acid from anionic columns are obtained using AG1-X8 columns, which show an extremely high selectivity for phytate and the capability of concentrating phytate from very diluted extracts ${ }^{15}$.

Thus, anion exchange chromatography may be a useful technique to effectively separate phytic acid from inorganic phosphate. Separation is $\mathrm{pH}$-dependant: phytic acid is strongly dissociated even at low $\mathrm{pH}$ values ( $\mathrm{pKa} 1=-0.15$, $\mathrm{pKa} 2=0.41$, $\mathrm{pKa} 3$ $=0.85$, pKa4 $=1.84)^{16}$ and is strongly retained in the resin, whereas phosphate, which has a 
lower dissociation at low $\mathrm{pH}$ values $(\mathrm{pKa} 1=2.12, \mathrm{pKa} 2=7.20$, pKa3 $=12.36)^{17}$ is relatively easily eluted from the resin by using diluted $\mathrm{HCl}$.

Optimisation of the phytic acid/phosphate separation and phytic acid recovery processes was carried out by using phosphate and phytic acid standards dissolved in water. Some of the results obtained after carrying out the separation/recovery process are summarized in Table I. $50 \mathrm{~mL}$ of eluent $A\left(\mathrm{HCl} 50 \mathrm{mmol} \mathrm{L}^{-1}\right)$ are required for the total elution of inorganic phosphate without significant elution of phytic acid and $2 \mathrm{~mL} \mathrm{HCl} 2.0 \mathrm{~mol} \mathrm{~L}^{-1}$ are required as eluent $B$ for the subsequent elution of the retained phytic acid.

Table I. Optimisation of phytic acid separation/recovery process.

\begin{tabular}{|c|c|c|c|c|c|}
\hline \multirow[b]{2}{*}{$\begin{array}{l}\text { Phosphate } \\
\qquad\left(\mathrm{mg} \mathrm{L}^{-1}\right)\end{array}$} & \multirow[b]{2}{*}{ Eluent $A^{a}$} & \multirow[b]{2}{*}{ Eluent B } & \multicolumn{3}{|c|}{ Phytic acid } \\
\hline & & & $\begin{array}{l}\text { Added } \\
\left(\mathrm{mg} \mathrm{L}^{-1}\right)\end{array}$ & $\begin{array}{l}\text { Found } \\
\left(\mathrm{mg} \mathrm{L}^{-1}\right)\end{array}$ & $\begin{array}{c}\text { Recovery } \\
\text { (\%) }\end{array}$ \\
\hline- & $50 \mathrm{~mL}$ & $5.0 \mathrm{~mL} \mathrm{HCl} 0.4 \mathrm{~mol} \mathrm{~L}^{-1}$ & 4.00 & 0.98 & 24.5 \\
\hline- & $50 \mathrm{~mL}$ & $2.0 \mathrm{~mL} \mathrm{HCl} 1.0 \mathrm{~mol} \mathrm{~L}^{-1}$ & 4.00 & 2.65 & 66.3 \\
\hline- & $50 \mathrm{~mL}$ & $1.0 \mathrm{~mL} \mathrm{HCl} 2.0 \mathrm{~mol} \mathrm{~L}^{-1}$ & 4.00 & 3.20 & 80.0 \\
\hline- & $50 \mathrm{~mL}$ & $1.5 \mathrm{~mL} \mathrm{HCl} 2.0 \mathrm{~mol} \mathrm{~L}^{-1}$ & 4.00 & 3.69 & 92.3 \\
\hline- & $10 \mathrm{~mL}$ & $2.0 \mathrm{~mL} \mathrm{HCl} 2.0 \mathrm{~mol} \mathrm{~L}^{-1}$ & 4.00 & 3.98 & 99.5 \\
\hline- & $30 \mathrm{~mL}$ & $2.0 \mathrm{~mL} \mathrm{HCl} 2.0 \mathrm{~mol} \mathrm{~L}^{-1}$ & 4.00 & 4.00 & 100.0 \\
\hline - & $50 \mathrm{~mL}$ & $2.0 \mathrm{~mL} \mathrm{HCl} 2.0 \mathrm{~mol} \mathrm{~L}^{-1}$ & 4.00 & 4.01 & 100.3 \\
\hline 1500 & $30 \mathrm{~mL}$ & $2.0 \mathrm{~mL} \mathrm{HCl} 2.0 \mathrm{~mol} \mathrm{~L}^{-1}$ & - & 0.02 & - \\
\hline 2500 & $30 \mathrm{~mL}$ & $2.0 \mathrm{~mL} \mathrm{HCl} 2.0 \mathrm{~mol} \mathrm{~L}^{-1}$ & - & 0.05 & - \\
\hline 3500 & $30 \mathrm{~mL}$ & $2.0 \mathrm{~mL} \mathrm{HCl} 2.0 \mathrm{~mol} \mathrm{~L}^{-1}$ & - & 0.08 & - \\
\hline 1500 & $50 \mathrm{~mL}$ & $2.0 \mathrm{~mL} \mathrm{HCl} 2.0 \mathrm{~mol} \mathrm{~L}^{-1}$ & - & 0.00 & - \\
\hline 2500 & $50 \mathrm{~mL}$ & $2.0 \mathrm{~mL} \mathrm{HCl} 2.0 \mathrm{~mol} \mathrm{~L}^{-1}$ & - & 0.01 & - \\
\hline 3500 & $50 \mathrm{~mL}$ & $2.0 \mathrm{~mL} \mathrm{HCl} 2.0 \mathrm{~mol} \mathrm{~L}^{-1}$ & - & 0.00 & - \\
\hline
\end{tabular}

${ }^{a}$ Eluent $\mathrm{A}$ was $\mathrm{HCl} 50 \mathrm{mmol} \mathrm{L}^{-1}$

Some real urine samples were analysed in presence and in absence of phytic acid spikes (Table II). Our results of phytic acid 
recovery from real urine samples show recoveries ranging from 98$102 \%$, indicating a good accuracy in the phytic acid determination without the need of pre-treatment other than filtering urine samples through $0.45 \mu \mathrm{m}$ pore filters.

Table II. Analysis of some human urine samples (mean \pm standard error of prediction; three determinations).

\begin{tabular}{cccc}
\hline & \multicolumn{3}{c}{ Phytic acid } \\
\cline { 2 - 4 } Sample & $\begin{array}{c}\text { Added } \\
\left(\mathrm{mg} \mathrm{L}^{-1}\right)\end{array}$ & $\begin{array}{c}\text { Found } \\
\left(\mathrm{mg} \mathrm{L}^{-1}\right)\end{array}$ & $\begin{array}{c}\text { Recovery } \\
(\%)\end{array}$ \\
& - & $1.05 \pm 0.04$ & - \\
A & 1.12 & $2.19 \pm 0.03$ & 101.8 \\
& - & $1.59 \pm 0.04$ & - \\
B & 0.97 & $2.54 \pm 0.03$ & 97.8 \\
\cline { 2 - 4 } C & - & $0.86 \pm 0.05$ & - \\
\cline { 2 - 4 } & 0.97 & $1.82 \pm 0.04$ & 99.2 \\
\hline
\end{tabular}

Analytical features of the method

Linearity and Limit of Detection

Linear range (0.02-0.6 mg phytic acid $\left.\mathrm{L}^{-1}\right)$ and limit of detection ( $5 \mu \mathrm{g} \mathrm{L}^{-1}$ phytic acid) are adequate for analysis of usual amounts of phytic acid in urine $\left(0.2 \text { to } 6.0 \mathrm{mg} \mathrm{L}^{-1}\right)^{13,14}$.

Study of Interferences

Urine samples present a complex matrix that contains potentially interfering species. Main interferences could be consequence of high amounts of inorganic phosphate and/or pyrophosphate in the urine samples that could difficult the separation process of phytic acid from other sources of phosphorus in the urine samples. $\mathrm{pH}$ of urine samples is another factor that could possibly affect the recovery of phytic acid from samples. Thus, the effect of phosphate, pyrophosphate and $\mathrm{pH}$ have been studied (Table III). A good recovery was obtained for almost all samples analysed, except for those with the highest phosphate 
spike and highest $\mathrm{pH}$, due to precipitation of calcium phosphates from urine and subsequent adsorption/occlusion of phytic acid in the

precipitates formed, indicating that phosphate, pyrophosphate and $\mathrm{pH}$ do not interfere the phytic acid determination, even with values clearly exceeding the physiological urinary range. However, if a precipitate forms from urine, deficient recoveries of phytic acid from analysed samples will be obtained. Thus, acidification with $\mathrm{HCl}$ to $\mathrm{pH}$ 3-4 to avoid precipitation from urine is greatly recommended, especially if sample is not analysed immediately after collection.

\section{Accuracy and precision}

The accuracy of the method was determined by the evaluation of phytic acid recoveries from 18 first-morning urine samples analysed by contrast with aliquots of spiked amounts of phytic acid. Recoveries ranged from 96 to 104\%, indicating good accuracy for the proposed method.

RSD values of $4.6,2.8$ and $2.0 \%$ were obtained from five replicates of real samples that, according to this procedure, contained $0.34,0.90$ and 1.59 mg phytic acid $L^{-1}$, respectively. 
Table III. Study of interferences. Determination of phytic acid in presence of phosphate, pyrophosphate and $\mathrm{pH}$ exceeding their usual physiologic ranges. Original sample contained $1225 \mathrm{mg} \mathrm{L}^{-1}$ of total $\mathrm{P}$ and $\mathrm{pH} 5.38$. Normal physiologic values: phosphate $\left(<1100 \mathrm{mg} \cdot \mathrm{day}^{-1}\right)$, pyrophosphate

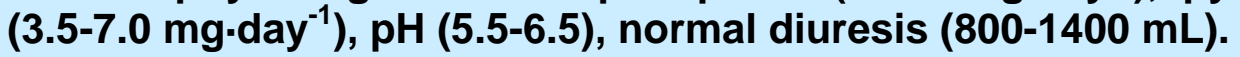

\begin{tabular}{|c|c|c|c|c|}
\hline \multirow[b]{2}{*}{$\begin{array}{c}\text { Phosphate } \\
\text { added } \\
\left(\mathrm{mg} \mathrm{L}^{-1}\right)\end{array}$} & \multirow[b]{2}{*}{$\begin{array}{l}\text { Pyrophosphate } \\
\text { added }\left(\mathrm{mg} \mathrm{L}^{-1}\right)\end{array}$} & \multirow[b]{2}{*}{ pH } & \multicolumn{2}{|c|}{ Phytic acid } \\
\hline & & & $\begin{array}{l}\text { Found } \\
\left(\mathrm{mg} \mathrm{L}^{-1}\right)\end{array}$ & $\begin{array}{c}\text { Recovery } \\
\text { (\%) }\end{array}$ \\
\hline- & - & 5.38 & 0.93 & - \\
\hline 1500 & - & - & 0.94 & 101.2 \\
\hline 3000 & - & - & 0.91 & 98.0 \\
\hline 4500 & - & - & 0.92 & 99.0 \\
\hline 6000 & - & - & 0.94 & 101.2 \\
\hline 7500 & - & - & 0.88 & 94.7 \\
\hline- & 12.5 & - & 0.96 & 103.3 \\
\hline- & 25.0 & - & 0.96 & 103.3 \\
\hline- & 37.5 & - & 0.95 & 102.3 \\
\hline- & 50.0 & - & 0.91 & 98.0 \\
\hline- & - & 3.90 & 0.91 & 98.0 \\
\hline- & - & 4.98 & 0.95 & 102.3 \\
\hline- & - & 6.06 & 0.96 & 103.3 \\
\hline- & - & 7.00 & 0.83 & 89.3 \\
\hline
\end{tabular}


Application of the method to urolithiasic patients

Applicability of the developed method was demonstrated by determining the phytic acid content of first-morning urine samples of healthy people as well as oxalocalcic lithiasic patients. Results collected in Table IV suggest that low urinary phytic acid concentration and low urinary phytic acid/calcium molar concentration ratios values are related with oxalocalcic urolithiasis. Thus, the proposed method can have a promising application in the prediction of risk to develop calcium urolithiasis illness.

Table IV. Phytic acid concentration in first-morning urine of oxalocalcic lithiasic patients and healthy controls. Values are represented as mean \pm SD.

\begin{tabular}{ccc}
\hline & $\begin{array}{c}\text { Healthy } \\
\text { controls }\end{array}$ & $\begin{array}{c}\text { Oxalocalcic lithiasic } \\
\text { patients }\end{array}$ \\
\cline { 2 - 3 } Individuals & 8 & 7 \\
$\mathrm{pH}$ & $5.67 \pm 0.14$ & $5.57 \pm 0.20$ \\
$\mathrm{Ca}\left(\mathrm{mg} \mathrm{L}^{-1}\right)$ & $165 \pm 50$ & $210 \pm 100$ \\
IP6 $\left(\mathrm{mg} \mathrm{L}^{-1}\right)$ & $1.19 \pm 0.36$ & $0.82 \pm 0.27$ * \\
IP6 / Ca \\
$\left(\times 10^{5}\right)$
\end{tabular}

* Significantly different from healthy controls by Student's t-test ( $p<$ 0.05)

\section{Conclusions}

The applicability of ICP-MS facilities on the determination of phytic acid in urine has been demonstrated. The lack of selectivity of ICP-MS measurement for phytic acid in urine is satisfactorily overcome by an extraordinarily selective anion-exchange purification process of phytic acid from other phosphorus components present in urine matrix. 
In contrast, ICP-MS gives excellent sensibility and low detection limits for accurate determination of phytic acid through ${ }^{31} \mathrm{P}$ measurement, even when low amounts of sample are used. The good agreement obtained between the phytic acid content in spiked aliquots and the values found in natural urines, demonstrate the suitability of the proposed analytical procedure.

Main characteristics of the method are its simplicity, low sample requirement, relatively high sample throughput (10 to 6 minutes per sample for runs between 50 to 100 samples, respectively), and high selectivity and sensibility. Thus, the present method provides the best alternative to current methods suitable for phytic acid determination in biological samples (such as urine), especially when considering their scarcity and long sample pretreatments (including several steps for purification, hydrolysis, derivatization, etc.).

This method can contribute to elucidate the action of phytic acid in urolithiasis and the possible relation of low phytic acid content in human samples with renal lithiasis. Accordingly, the developed method could be easily used by clinical chemists to establish normal and pathological levels of phytic acid in urine for a rational diagnostic or treatment of the urolithiasic illness.

\section{Acknowledgements}

J.A. Muñoz acknowledges the "Departament d'Universitats, Recerca i Societat de la Informació de la Generalitat de Catalunya" for the scholar-grant received. The work has been carried out under the support of the research Grant PPQ2002-04267-C03-01. 


\section{References}

1. March JG, Simonet BM, Grases F, Kinetic-turbidimetric determination of phytic acid by sequential injection analysis. Anal Chim Acta. 409: 9, 2000

2. Shamsuddin AM, Inositol phosphates have novel anticancer function. J Nutr. 125: 725, 1995

3. Thompson LU, Antioxidants and hormone-mediated health benefits of whole grains. Crit Rev Food Sci Nutr. 34: 473, 1994

4. Graf E, Eaton JW, Antioxidant functions of phytic acid. Free Radical Biol Med. 8: 61,1990

5. Grases F, Garcia-Ferragut L, Costa-Bauzá A, March JG, Study of the effects of different substances on the early stages of papillary stone formation. Nephron. 73: 561, 1996

6. Modlin $M$, Urinary phosphorylated inositols and renal stone. Lancet. 2: 1113, 1980

7 Grases F, Llobera A. Determination of phytic acid in urine by ICP atomic emission spectrometry. Anal Letters. 29: 1193, 1996

8 Grases F, March JG, Prieto RM, Simonet BM, Costa-Bauzá A, García-Raja A, Conte A, Urinary phytate in calcium oxalate stone formers and healthy people. Scand J Urol Nephrol. 34: 162, 2000

9 Buscher BAP, Van der Hoeven RAM, Tjaden UR, Andersson E, Van der Greef J, Analysis of inositol phosphates and derivatives using capillary zone electrophoresis-mass spectrometry. J. Chromatogr A. 712: 235, 1995 
10. Burbano C, Muzquiz M, Osagie A, Ayet G, Cuadrado C, Determination of phytate and lower inositol phosphates in Spanish legumes by HPLC methodology. Food Chem. 52: 321, 1995

11. Casals I, Villar JL, Riera-Codina M, A straightforward method for analysis of highly phosphorylated inositols in blood cells by highperformance liquid chromatography. Anal Biochem. 300: 69, 2002

12. Sekiguchi $Y$, Matsunaga A, Yamamoto A, Inoue $Y$, Analysis of condensed phosphates in food products by ion chromatography with an on-line hydroxide eluent generator. J Chromatogr A. 881: 639, 2000

13. March JG, Simonet BM, Grases F, Determination of phytic acid by gas chromatography-mass spectroscopy: application to biological samples J Chromatogr B. 757: 247, 2001

14 March JG, Simonet BM, Grases F, Salvador A, Indirect determination of phytic acid in urine. Anal Chim Acta. 367: 63, 1998

15. Maga JA, Phytate: its chemistry, occurrence, food interactions, nutritional significance, and methods of analysis J Agric Food Chem. 30: 1, 1982

16. Brigando C, Mossoyan JC, Favier F, Benlian D, Conformational preferences and protonation sequence of myo-inositol hexaphosphate in aqueous solution; potentiometric and multinuclear magnetic resonance studies. J Chem Soc Dalton Trans. 4: 575, 1995

17. Dean, J.A. (ed.), Lange's Handbook of Chemistry, McGraw-Hill Book Company, New York, 1973 